\section{Use of Silver Nanoparticles Reduces Internal Contamination of External Hexagon Implants by Candida albicans}

Victor Haruo Matsubara, Fernando Igai, Regina Tamaki, Pedro Tortamano Neto, Atlas Edson Moleros Nakamae, Matsuyoshi Mori
Department of Prosthodontics, Dental School, USP - University of São Paulo, São Paulo, SP, Brazil

Correspondence: Victor Haruo Matsubara, Av. Professor Lineu Prestes, 2227; Cidade Universitária, 05508-000 São Paulo, SP, Brasil. Tel: +55-113091-7888. e-mail: vicmats@usp.br

\begin{abstract}
Since the dental implant/abutment interface cannot totally seal the passage of microorganisms, the interior of implant becomes a reservoir of pathogenic microorganisms that produce and maintain chronic inflammation in the tissues around implants. Silver nanoparticles (nano-Ag) are potent and broad-spectrum antimicrobial agents. The aim of this study was to evaluate the capacity of the nano-Ag to prevent the contamination of the implant internal surface by Candida albicans, caused by the implant/abutment microgap infiltration. Thirty-six implants were used in this experiment. Three study groups were performed: experimental group (implants receiving an application of nano$\mathrm{Ag}$ in their inner cavity before installation of the abutment); positive-control group (implants receiving sterile phosphate buffer saline application instead of nano-Ag) and negative-control group (implants receiving the application of nano-Ag in the inner cavity and immersed in a sterile medium). In the positive-control and experimental groups, the implants were immersed in a Candida albicans suspension. The abutments of all three groups were screwed with a $10 \mathrm{~N}$ torque. After $72 \mathrm{~h}$ of immersion in C. albicans suspension or sterile medium, the abutments were removed and the inner surface of the implants was sampled with absorbent paper cone for fungal detection. No C. albicans contamination was observed in the negative-control group. The positive-control group showed statistically higher values of colony forming units (CFUs) of C. albicans compared with the experimental group. In conclusion, silver nanoparticles reduced C. albicans colonization inside the implants, even with low torque screw abutment.
\end{abstract}

Key Words: dental implants, nano-Ag, Candida albicans, implant/abutment interface.

\section{Introduction}

Dental implant treatment is currently a predictable and affordable method of oral rehabilitation, in some cases they are preferred over the classical alternatives of treatment such as removable or fixed prosthesis. Longterm success of implant-based treatment depends on the control of mechanical and biologic factors (1). Mechanical factors include the static and dynamic occlusal load on the prosthetic crowns and implants. In turn, biological factors also play a very important role in the short and long term success of a dental implant (2). It is known that peri-implant infections can produce discomfort to the patient and also accelerate bone loss (3).

There are many studies showing that the implant/ abutment interface cannot totally seal the passage of microorganisms, regardless of the implant/abutment connection type (internal, external or morse taper connections) $(4,5)$. Even well adapted interfaces, with less than $5 \mu \mathrm{m}$ microgap, were shown to be unable to prevent infiltration and the consequent bacterial colonization inside the implants (2). Thus, the internal colonization of the implant surface by microorganisms is eventually inevitable. The interior of implant becomes a reservoir of pathogenic microorganisms, promoting and maintaining a chronic inflammation in tissues around the implants (6).
This condition causes bone loss and may lead to failure of the implant treatment (4).

On average, modern implants show better clinical results than previous generations of implants (7). One reason for this improvement is that several contemporary implant systems try to prevent microbial contamination at the implant/abutment interface. The design of morse taper connection implants suggests that they provide a total seal (8), but literature shows that this system is not able to prevent the passage of fluids and microorganisms (4). Also, the external hexagonal design is prone to microbial invasion in comparison with other implant connections (9). Platform-switched implants appeared with the concept of increasing distance to implant/abutment interface from the bone surface, and thereby decrease bone resorption produced by the presence of microorganisms in the implant/ abutment microgap. Platform-switched implants have been shown to be effective in reducing bone loss caused by microbial factors (10), but not all implant systems have platform-switched abutments.

There is a concept that the implants behave as teeth and, therefore, can potentially suffer from the same diseases (3). The main difference lies in the term itself, periodontitis is reserved for teeth, whereas peri-implantitis is specific to implants (3). The specific plaque hypothesis established 
the role of some microorganisms such as Aggregatibacter actinomycetemcomitans, Porphyromonas gingivalis, Tannerella forsythensis, Treponema denticola, Prevotella intermedia and Fusobacterium nucleatum in different forms of periodontal diseases. It has been recently suggested that these suspected periodontal pathogens seem to act not alone and the interactions between species, especially the balance between pathogenic and beneficial species, affect both progression of disease and response of tissues to periodontal therapy (11). It has been established that the plaque formation starts with the deposition of a salivary pellicle on the tooth surface. Planktonic cells or aggregates of cells adhere to this pellicle via specialized adhesins on the bacterial cell surface that recognize pellicle proteins, and/or by the mechanisms of non-specific physicochemical interactions (12). This process results in a scattered pattern of bacterial deposits with the presence of initial colonizers (13). The initial colonizers facilitate the formation of bacterial biofilms and Candida sp are an example of initial colonizers (13). The biofilms formed on the implant surface have several common characteristics with dental biofilms, including the sequence of microbial colonization (14).

Different ways of preventing the passage of microorganisms through the implant/abutment interface have been investigated, such as varnish containing 1\% chlorhexidine $(5,15)$ and silicone sealants $(5)$. The latter was unable to prevent bacterial infiltration and there is no consensus on the capacity of varnish-containing chlorhexidine in sealing the passage of microorganisms through the microgap (5).

Considering the reasons of bone loss around implants and the options of implants currently available, an effective and affordable alternative has to be developed to prevent or reduce microorganism colonization inside the implants, reducing the peri-implant bone loss regardless of the implant system connection, and therefore increasing the prognosis of implant treatment.

In the past few years, nanotechnology emerged as a new technology to fight and prevent disease using atomic scale materials. Among the most promising nanomaterials with antibacterial properties are the metallic nanoparticles such as silver nanoparticles (nano-Ag). Current knowledge of the antimicrobial property of silver, involving the biochemical and molecular basis, has been documented since 1998 (16). The emergence of nanotechnology and electronics, and confocal microscopes able to display dimensions from 0.1 to 100 nanometers $(\mathrm{nm})$, has enabled the study of materials on a nanometric scale. Nanometric materials have proven to have different properties, characteristics and behaviors from those presented on macro or micrometer scales. When silver is displayed in nanometric format $(<10 \mathrm{~nm})$, interesting characteristics show up, such as larger total surface area, which significantly enhances its antimicrobial activities (17).

The silver nanoparticles are potent and broad-spectrum antimicrobial agents. They are used in food preservation and are scientifically recommended for the treatment of a number of diseases in various fields of medicine (16). Furthermore, the use of nano-Ag is considered to be safe and can be easily manufactured with low production costs (16). Nano-Ag can be produced by laser ablation or by chemical methods (18). These particles have shown high antimicrobial and bactericidal activity against Gram-positive and Gram-negative bacteria, including highly multiresistant strains such as methicillin-resistant Staphylococcus aureus (19). They also possess antifungal properties (16).

Candida albicans is the most common yeast found in the oral cavity and it is known for its ability to colonize medical devices. It has been shown that $C$. albicans is able to adhere to various types of implant surfaces and to colonize the interior surface of implants through the implant/abutment microgap (20). Candida spp is an initial colonizer, and plays a role in the formation of bacterial biofilms (13). Thus, the reduction or inhibition of C. albicans colonization on the surface of implants will reduce the formation of bacterial biofilms and consequently prevent bone loss caused by microbiologic factor.

The aim of this study was to evaluate the capacity of silver nanoparticles in preventing contamination on the internal surface of implants with external hexagonal connection by Candida albicans, caused by the implant/ abutment microgap infiltration.

\section{Material and Methods}

\section{Candida albicans Strain and Culture Conditions}

Candida albicans strain SC5314 was used in this study and stored in tubes containing Sabouraud dextrose agar (SDA) (Difco, Detroit, MI, USA) and glycerol at $-20{ }^{\circ} \mathrm{C}$ until use. Strain SC5314 is a virulent human clinical isolate with a sequenced genome. To prepare the Candida albicans suspension, the yeast cells were cultured in Sabouraud dextrose broth (SDB) (Difco) for $24 \mathrm{~h}$ at $25^{\circ} \mathrm{C}$ in a shaking water bath. The blastospores were transferred into fresh medium and cultured at $25^{\circ} \mathrm{C}$ for further $18 \mathrm{~h}$. Yeast cells were harvested by centrifugation $(2,000 \mathrm{Xg}$ for $10 \mathrm{~min})$, washed twice in phosphate-buffered saline (PBS), and resuspended in SDB to yield a concentration of $1 \times 10^{7}$ blastospores per $\mathrm{mL}$ in PBS until use in a spectrophotometer.

\section{In Vitro Model}

All experiments were carried out by a single investigator in a sterile environment. Three groups were established: one experimental group, with implants that received application of nano-Ag suspension (KHEMIA, São Paulo, SP, Brazil) on 
their internal screw surface before the installation of the abutment; one positive control group, with implants that received the application of sterile PBS instead the nanoAg suspension on the internal screw surface. In these two groups, the implants/abutment units were immersed in the C. albicans suspension. The third group was the negative control group, with implants that received the application of nano-Ag suspension before the abutment installation and were immersed in sterile SDB. All groups were formed using external hexagon implants (Neodent ${ }^{\circledR}$, Curitiba, PR, Brazil) and abutments for temporary crowns (Neodent). All abutments and screws were sterilized before use and all the materials were handled in a flow chamber to avoid external contamination.

In the experimental group, $10 \mu \mathrm{L}$ of nano-Ag suspension (320 parts per million - ppm) was applied to the implants' inner cavity, where the threads for fixing the abutment screw are located. This volume was enough to fill the entire inner cavity of each implant. Abutments were seated carefully on the implant bodies and screwed with $10 \mathrm{~N}$ torque. The implants-abutment units were then immersed individually into sterile $1.5 \mathrm{~mL}$ eppendorfs containing $1 \mathrm{~mL}$ - of C. albicans suspension ( $\left.1 \times 10^{7} \mathrm{CFU} / \mathrm{mL}\right)$. This volume was enough to cover the implant/abutment interface (20).

In the positive-control group, $10 \mu \mathrm{L}$ of sterile PBS were introduced in the implants' inner cavity, instead of the nano-Ag suspension. The implant-abutment units were immersed in the $C$. albicans suspension as in the experimental group. In the negative control group, $10 \mu \mathrm{L}$ of nano-Ag suspension were introduced in the implant inner cavity before abutment installation. The implant-abutment units were then immersed into sterile $1.5 \mathrm{~mL}$ eppendorfs containing $1 \mathrm{~mL}$ of sterile SDB.

All groups were incubated at $37^{\circ} \mathrm{C}$ for $72 \mathrm{~h}$. After the incubation, all implant/abutment units were removed from the eppendorf tubes (with Candida suspension or sterile medium) and dried with sterile paper towels. The outer surface of the implant-abutment units was disinfected with $70 \%$ alcohol and air dried (15). The abutments were carefully removed from the implants and the surface of the implants inner cavity was sampled with sterile absorbent paper cone to detect fungal contamination (5). These paper cones were placed in Eppendorf tubes containing $1.0 \mathrm{~mL}$ of sterile PBS and homogenized in a vortex mixer. Ten serial dilutions were plated $(25 \mu \mathrm{L})$ in triplicate on the surface of agar plates (Sabouraud dextrose agar with chloramphenicol) (Difco), incubated at $32{ }^{\circ} \mathrm{C}$ and examined daily for two days. The number of grown Candida albicans CFUs $\mathrm{mL}^{-1}$ was calculated.

\section{Statistical Analysis}

Data are expressed as mean \pm standard deviation (SD) from at least two independent experiments. One-way ANOVA and Tukey's multiple-comparison test was used for statistical analysis. Statistical significance was set at $p<0.05$.

\section{Results}

In this experiment a total of 36 implants (12 implants for each group) were used to study the effect of silver nanoparticles on the $C$. albicans colonization inside implants with external hexagonal connection. Four implants (two from experimental group and two from positivecontrol group) were excluded from the microbiological analysis as their internal cavities became contaminated with the $C$. albicans suspension while the abutments were being removed. Thus, a total of 10 implants remained for analysis in both experimental and positive-control groups. The negative-control group was performed to show that the implants and abutments did not have prior $C$. albicans contamination. No growth of $C$. albicans colonies was observed in the negative control group. In the other two groups (experimental and positive control groups) was observed the presence of $C$. albicans CFUs on the surface of SDA plates after $48 \mathrm{~h}$ incubation. The results of this study are presented in Figure 1, which illustrates the experimental data. The number of CFUs in the experimental group was statistically lower compared to the results in the positive control group $(p<0.05)$. The statistically significant decrease

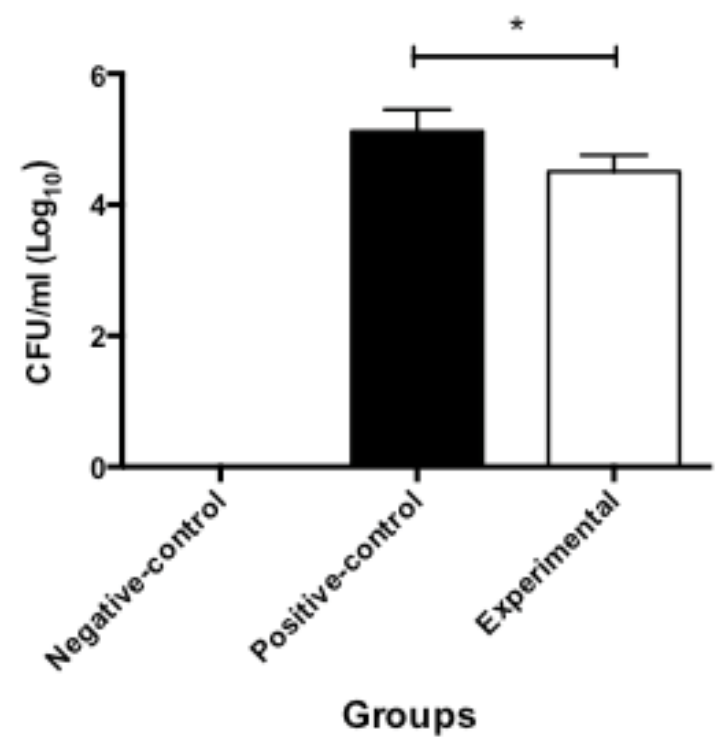

Figure 1. Comparative analysis of isolated C. albicans from the inner surface of external hexagon implants after being the implant/abutment unit immersed into C. albicans suspension or sterile medium for $72 \mathrm{~h}$. Experimental group received pretreatment with a 320 parts per million nano-Ag solution. The positive-control group was pretreated with PBS instead of nano-Ag. Statistics performed using one-way ANOVA followed by Tukey's multiple-comparison test. Data are presented as mean \pm SD. ${ }^{*}$ Differences were considered significant when $(p<0.05)$. 
of $C$. albicans colonization in the experimental group indicates that the silver nanoparticles were effective for inhibiting C. albicans growth inside the implants after 72 $\mathrm{h}$ in contact with a C. albicans suspension.

\section{Discussion}

The presence of microorganisms inside implants can be a reservoir of peri-implant pathogens that may contact bone around the implant via the implant-abutment interface (6). This exposure of pathogens results in different types of inflammatory reactions in peri-implant soft tissues, and can ultimately lead to bone loss and implant failure (21).

The presence of microorganisms in the implant/ abutment microgap may not cause significant bone loss that would greatly compromise the rehabilitation in a short term (7). However, it will be significant in an aesthetic location, as even minimal bone loss will affect the quantity and quality of bone surrounding implants and consequently, compromise the shape and contour of the overlying soft tissues (22).

This study attempts bringing evidence that silver nanoparticles can be an effective and convenient alternative in reducing the microorganism contamination at the implant/abutment interface, regardless of the design of the implant/abutment connection. The results showed that the silver nanoparticles suspension with a concentration of $320 \mathrm{ppm}$ was effective for reducing the number of viable $C$. albicans cells inside the implants with external hexagonal connection after being placed in an environment contaminated with C. albicans for $72 \mathrm{~h}$.

A previous study has shown that $C$. glabrata and $C$. albicans were able to flow into the inner cavity of implants through the implant/abutment interface and establish a mixed biofilm of fungi and bacteria (20). Thus, Candida spp may be associated with bacterial biofilm in the pathogenesis of peri-implantitis.

The abutment screw torque used in this experiment was lower than the one suggested by the manufacturer's protocol. The reason for the reduced torque was to facilitate the penetration of $C$. albicans through the implant/ abutment microgap, since pilot studies showed that little or no amount of fungus could penetrate inside the implants when the manufacturer's recommended abutment torque $(32 \mathrm{~N})$ was used. This happened possibly due to the size of yeast-like cells or blastoconidia, 2.0-4.0 x 3.0-5.5 $\mu \mathrm{m}$ in size (23) and the short exposure time to a $C$. albicans suspension.

The torque values suggested by the manufacturer are important to achieve the best coupling effect in relation to the system geometry (20). However, clinically adhering to the manufacturer's recommended abutment torque, the masticatory loads on the prosthetic crowns create microgaps in the implant/abutment interface that allows both bacterial and yeast penetration into the implants. In this study, the application of nano-Ag inside the implants reduced the quantity of viable fungal cells detectable on the internal surface of the implants. This result supports the hypothesis that nano-Ag can be used to reduce the formation of $C$. albicans reservoirs and consequently reduce the bacterial colonization inside the implants, since $C$. albicans is an initial colonizer associated with the formation of bacterial biofilms inside implants $(13,20)$.

Some possible mechanisms of action may be involved in the antimicrobial activity of silver nanoparticles. Nano-Ag can be interacting with components of the cell membrane of microorganisms, causing structural damage, forcing the dissipation of protons and promoting cell death (24). Nano-Ag has illustrated the ability to collapse the plasma membrane potential, causing a depletion of the levels of intracellular ATP (24). Silver ions ( $\mathrm{Ag}+$ ), released from the silver nanoparticles, can diffuse phosphorus of the DNA molecules resulting in the inactivation of replication and these ions can also react with sulfur-containing proteins, leading to the inhibition of enzyme function (25). Silver is also known to inhibit a number of oxidative enzymes such as yeast alcohol dehydrogenase, affecting the Candida cell survival (25).

The effective concentrations of silver nanoparticles and $\mathrm{Ag}+$ ions are at nanomolar $(\mathrm{nm})$ and micromolar $(\mu \mathrm{m})$ levels, respectively. Nano-Ag appears to be significantly more efficient than $\mathrm{Ag}+$ ions in mediating their antimicrobial activities (24). The concept of nanotechnologies is based on size-dependent properties of particles in the 1-100 $\mathrm{nm}$ range. However, the smaller silver particle size has more efficient cell-particle contact resulting in higher intracellular bioavailability, and consequently more toxicity (17). It suggests that there is a size-dependent biologic effect in silver nanoparticles.

It must be pointed out that the present in vitro test showed reduced contamination of $C$. albicans in the presence of silver nanoparticles, even though the implant/ abutment units were not under any occlusal load. Higher fungal contamination would be expected if the implants were under masticatory forces. Thus, mechanical cycling test must be performed to test the efficiency of silver nanoparticles in reducing or avoiding the contamination of the implant inner cavity by microorganisms when the implants are under occlusal loads.

Within the limits of this study, it can be concluded that the application of silver nanoparticles in the inner cavity of implants with external hexagonal connections reduces the colonization of $C$. albicans on its internal surfaces, even when the abutment is screwed with a low torque. The use of silver nanoparticles can be an effective supplemental 
therapy to reduce bone loss around implants caused by microbiological factors. The results and the methodology of the present study create base of knowledge for further studies testing silver nanoparticles against different bacteria associated with peri-implantitis. More in vitro and in vivo studies are required to prove that silver nanoparticles can produce beneficial results in implant treatment.

\section{Resumo}

A interface implante/pilar não pode ser totalmente selada para passagem de microrganismos, com isso o interior do implante torna-se um reservatório de microrganismos patogênicos que promovem e mantêm a inflamação crônica nos tecidos em volta dos implantes. Nanopartículas de prata são agentes antimicrobianos potentes e de amplo espectro. 0 objetivo deste estudo foi avaliar a capacidade das nanopartículas de prata em evitar a contaminação por Candida albicans do interior de implantes, originada da infiltração do fungo através da interface implante/pilar. 36 implantes foram utilizados neste experimento. Três grupos de estudo foram estabelecidos: grupo experimental (os implantes receberam aplicação de nanopartículas de prata na sua cavidade interna, antes da instalação do pilar); grupo controle positivo (os implantes receberam PBS estéril em vez das nanopartículas de prata) e grupo controle negativo (implantes receberam aplicação de nanopartículas de prata na cavidade interna, mas os implantes foram imersos em meio estéril). Nos grupos controle positivo e experimental, os implantes foram imersos em suspensão de Candida albicans. Os pilares protéticos de todos os grupos foram parafusados com torque de $10 \mathrm{~N}$. Após $72 \mathrm{~h}$ imersos na suspensão de $C$. albicans ou em meio $\vec{\nabla}$ estéril, os pilares foram removidos e amostras da superficie interna dos implantes foram coletadas com cone de papel absorvente para a detecção de Candida. No grupo controle negativo não foi observada contaminação por C. albicans. 0 grupo-controle positivo mostrou valores de unidades formadoras de colônia de Candida estatisticamente maiores quando comparado com o grupo experimental. Conclui-se que nanopartículas de prata reduzem a colonização de $C$. albicans dentro dos implantes, mesmo quando o pilar é parafusado com torque baixo.

\section{Acknowledgements}

The authors are grateful to Dr. Karin Hitomi Ishikawa and Dr. Washington Steagall Junior for making the statistical analysis of this study, Mr. Hooman Baghaie for his assistance in the English editing of the manuscript, KHEMIA Equipamentos Tecnológicos de Efluantes Ltda for providing the nano-Ag suspension and FAPESP for financial support.

\section{References}

1. Qian J, Wennerberg A, Albrektsson T. Reasons for marginal bone loss around oral implants. Clinical Implant Dentistry and Related Research 2012;14:792-807.

2. Passos SP, Gressler May L, Faria R, Ozcan M, Bottino MA. Implantabutment gap versus microbial colonization: Clinical significance based on a literature review. J Biomed Mater Res B Appl Biomater 2013;101:1321-1328.

3. Vázquez Álvarez $R$, Pérez Sayáns $M$, Gayoso Diz $P$, García García A. Factors affecting peri-implant bone loss: a post-five-year retrospective study. Clin Oral Implants Res 2015;26:1006-1014.

4. Ricomini Filho AP, Fernandes FS, Straioto FG, da Silva WJ, Del Bel Cury AA. Pre-load loss and bacterial penetration on different implantabutment connection systems. Braz Dent J 2010;21:123-129.

5. Duarte AR, Rossetti PH, Rossetti LM, Torres SA, Bonachela WC. In vitro sealing ability of two materials at five different implant-abutment surfaces. J Periodontol 2006;77:1828-1832.

6. Jansen VK, Conrads G, Richter EJ. Microbial leakage and marginal fit of the implant-abutment interface. Int J Oral Maxillofac Implants 1997:12:527-540.

7. Albrektsson T, Buser D, Sennerby L. Crestal bone loss and oral implants. Clinical Implant Dentistry and Related Research 2012;14:783-791.

8. Nentwig GH, Moser W, Mairgünther R. Das Ankylos-Implantat System. Implantologie 1993;3:225-237.

9. Quirynen $M$, Vogels R, Peeters W, van Steenberghe D, Naert I, Haffajee A. Dynamics of initial subgingival colonization of 'pristine' periimplant pockets. Clinical Oral Implants Research 2006;17:25-37.

10. Lazzara RJ, Porter SS. Platform switching: a new concept in implant dentistry for controlling post-restorative crestal bone levels. Int J Periodontics Restorative Dent 2006;26:9-17.

11. Feres $M$, Cortelli SC, Figueiredo LC, Haffajee AD, Socransky SS. Microbiological basis for periodontal therapy. Journal of Applied Oral Science: Revista FOB 2004;12:256-266.

12. Yao Y, Berg EA, Costello CE, Troxler RF, Oppenheim FG. Identification of protein components in human acquired enamel pellicle and whole saliva using novel proteomics approaches. The Journal of Biological Chemistry 2003;278:5300-5308.

13. Zijnge $V$, van Leeuwen MB, Degener JE, Abbas F, Thurnheer $T$, Gmur R, et al.. Oral biofilm architecture on natural teeth. PloS One 2010;5:e9321.

14. Tanner A, Maiden MF, Lee K, Shulman LB, Weber HP. Dental implant infections. Clinical infectious diseases: an official publication of the Infectious Diseases Society of America 1997;25Suppl2:213-217.

15. Besimo CE, Guindy JS, Lewetag D, Meyer J. Prevention of bacterial leakage into and from prefabricated screw-retained crowns on implants in vitro. Int J Oral Maxillofac Implants 1999;14:654-660.

16. Percival SL, Bowler PG, Russell D. Bacterial resistance to silver in wound care. The Journal of Hospital Infection 2005;60:1-7.

17. Ivask A, Kurvet I, Kasemets K, Blinova I, Aruoja V, Suppi S, et al.. Sizedependent toxicity of silver nanoparticles to bacteria, yeast, algae, crustaceans and mammalian cells in vitro. PloS One 2014;9:e102108. doi: 10.1371/journal.pone.0102108 (Epub ahead of print).

18. Cushing BL, Kolesnichenko VL, O'Connor CJ. Recent advances in the liquid-phase syntheses of inorganic nanoparticles. Chemical Reviews 2004;104:3893-3946.

19. Zarei M, Jamnejad A, Khajehali E. Antibacterial effect of silver nanoparticles against four foodborne pathogens. Jundishapur Journal of Microbiology 2014;7:e8720. doi: 10.5812/jjm.8720. (Epub ahead of print)

20. Baggi L, Di Girolamo M, Mirisola C, Calcaterra R. Microbiological evaluation of bacterial and mycotic seal in implant systems with different implant- abutment interfaces and closing torque values. Implant Dent 2013;22:344-350.

21. Ericsson I, Persson LG, Berglundh T, Marinello CP, Lindhe J, Klinge $B$. Different types of inflammatory reactions in peri-implant soft tissues. J Clin Periodontol 1995;22:255-261.

22. Tesmer $\mathrm{M}$, Wallet $\mathrm{S}$, Koutouzis $\mathrm{T}$, Lundgren $\mathrm{T}$. Bacterial colonization of the dental implant fixture-abutment interface: an in vitro study. J Periodontol 2009;80:1991-1997.

23. Dignani M, Solomkin J, Anaissie E: Candida. In: Elsevier CL, (Editor): Clinical Mycology, 2009.

24. Lok CN, Ho CM, Chen R, He QY, Yu WY, Sun H, et al.. Proteomic analysis of the mode of antibacterial action of silver nanoparticles. Journal of Proteome Research 2006;5:916-924.

25. Matsumura Y, Yoshikata K, Kunisaki S, Tsuchido T. Mode of bactericidal action of silver zeolite and its comparison with that of silver nitrate. Applied and Environmental Microbiology 2003;69:4278-4281.

Received February 24, 2015 Accepted May 20, 2015 